\title{
Antimicrobial Test of 1-(2.5-Dihydroxi Phenyl)-(3- Pyridine-2-II) -Propanone Compound in Enterococcus Faecalis and Escherichia Coli Bacteria Using a Well Diffusion Method
}

\section{Andy Eko Wibowo*; Rivaldy Rifai Hatala; dan Awaluddin M Edang}

School of Pharmacy, Faculty of Medicine and Health Science, Universitas Muhammadiyah Yogyakarta, Jl Brawijaya, Tamantirto, Kasihan, Bantul, Yogyakarta 55183

\begin{abstract}
1-(2.5-dihydroxy phenyl)-(3-pyridine-2-il)-propenone compound is a compound synthesized by reacting the pyridine-2-carbaldehyde and 2.5-dihydroxyacetophenone compound without solvent with $\mathrm{K}_{2} \mathrm{CO}_{3}$ (Potassium Carbonate) catalyst in the microwave. The 1(2.5-dihydroxy phenyl)-(3-pyridine-2-il)-propenone compound is a chalcone derivative compound substituted by two hydroxy groups on ring $A$ and has 2-pyridyl groups on ring $B$. Chalcone is a secondary metabolite compound from the flavonoid group, which has several activities as anti-platelet, anti-bacterial, immunomodulator, anti-hyperglycemic, and anti-inflammatory. This study aims to determine the antibacterial effect of 1-(2.5dihydroxifenil)-(3-pyridine-2-il)-propenone compound against Enterococcus faecalis and Escherichia coli bacteria. This study used TLC (Thin Layer Chromatography) and Melting Point Test to analyze the purity of 1-(2.5-dihydroxy phenyl)-(3-pyridine-2-il)propenone compound. Meanwhile, the test for antibacterial activity used a well diffusion method. Concentration variation for 1-(2.5-dihydroxifenyl)-(3-pyridine-2-il)-propenone compound as antibacterial in Escherichia coli were $0.25 \mathrm{mg} / 100 \mu \mathrm{l}, 0.5 \mathrm{mg} / 200 \mu \mathrm{l}$, and $0.75 \mathrm{mg} / 300 \mu \mathrm{l}$. Meanwhile, the concentration variation for Enterococcus faecalis bacteria was 5\%, 2.5\%, $1.25 \%$ and was replicated three times. The results of the compound purity test using the melting point test and Thin Layer Chromatography (TCL) showed that the 1-(2.5-dihydroxy phenyl)-(3-pyridine-2-il)propenone compound was pure. The results of the antibacterial activity test for 1-(2.5-dihydroxiphenyl)-(3-pyridine-2-il)propenone compound showed no zone of inhibition at each test concentration. In conclusion, the 1-(2.5-dihydroxifenyl)-(3pyridine-2-il)-propenone compound did not have an antibacterial effect on Enterococcus faecalis and Escherichia coli bacteria.
\end{abstract}

Keywords: 1-(2.5-dihydroxiphenyl)-(3-pyridine-2-yl) -propenon; antibacterial; Chalcone compounds; Enterococcus faecalis; Escherichia coli

\section{Data of article}

Received : 28 Dec 2020

Reviewed : 20 Jan 2021

Accepted : 22 Feb 2021

DOI

10.18196/jfaps.v1i2.10983

Type of article:

Research

\footnotetext{
*Corresponding author,e-mail: andyew@umy.ac.id
} 


\section{INTRODUCTION}

There have been many studies on new compounds whose efficacy is still not significantly known all this time. One of them is 1-(2.5-hydroxyphenyl)-(3pyridine-2-il)-propenone compound, a synthesis of chalcone derivative compounds that have several benefits in it 3 . Chalcone is one of the flavonoids which has a C6-C3-C6 framework. Derivatives of this compound have an essential role in nature and the world of health. Chalcone and its derivatives have several activities that can be utilized in the pharmaceutical field, such as anti-platelet, anti-bacterial, immunomodulatory, anti-hyperglycemic, and anti-inflammatory ${ }^{1}$. Therefore, these compounds' biological activity and potential are significant and beneficial for drug development, and some efforts are needed to develop the synthesis of chalcone and its derivatives ${ }^{2}$. One example of a compound that contains chalcone is the ashitaba plant, which also contains alkaloids.

The 1-(2.5-dihydroxy phenyl)-(3-pyridine2-il)-propenone compound is a chalcone derivative compound substituted by two hydroxy groups in ring $A$ and has 2-pyridyl groups on ring $\mathrm{B}$. The compound is obtained from synthesis using the microwave method. The synthesis is from 2.5-dihydroxyacetophenone and pyridine2-carbaldehyde compound with $\mathrm{K}_{2} \mathrm{CO}_{3}$ catalyst without solvent, taking 4 minutes using a 140-watt microwave power ${ }^{3}$. Based on this background, this study aims to determine the antimicrobial activity of 1-(2.5-Dihydroxyphenyl)-(3-Piridin-2-II)propenone compound, which was tested on Enterococcus faecalis and Escherichia coli by the well diffusion method.

\section{METHOD}

\section{Tools and Materials}

The tools used in this study were aluminum foil (Klin Pak $\left.^{\circledR}\right)$, label (Brand $\left.{ }^{\circledR}\right)$, blue tip (Pipette Tip ${ }^{\circledR}$ ), yellow tip (Pipette Tip $\left.^{\circledR}\right)$, glassware (Prex $\left.{ }^{\circledR}\right)$, analytical scales (Casbee $\left.{ }^{\circledR}\right)$, ose, tweezers, micropipette (Gilson ${ }^{\circledR}$ ), incubator (Memmert ${ }^{\circledR}$ ), laminar airflow (LAF), hot plate (Thermo Scienific ${ }^{\circledR}$ ), autoclave (All American ${ }^{\circledR}$ ), Spatel, Capillary Tube, Chamber, Mortir Stamper, Melting point apparatus, UV Viewing Cabinet, and Vortex Mixer.

Meanwhile, the materials used in the study were dry simplicia of 1-(2.5-dihydroxy phenyl)-(3-pyridine-2-il)-propenone

compound, DMSO, distilled water (Brataco $\left.{ }^{\circledR}\right)$, chloroform $\left(\mathrm{CHCl}_{3}\right)$, sodium chloride $(\mathrm{NaCl}), \mathrm{N}$-hexane, ethyl acetate, Ethanol 70\%, and Silica Gel 6o GF 254.

The test microbes used in this study were Escherichia coli ATCC 25922 and Enterococcus faecalis ATCC 29212. The comparative antibiotic was Amoxicillin, and the media was Nutrient Agar (NA). This study was conducted in the pharmaceutical technology laboratory and microbiology laboratory at University Muhammadiyah Yogyakarta.

\section{Method of Compound Purity Test}

\section{Purity Test by Thin Layer Chromatography (TLC)}

The compound purity test was to determine the purity of the compound, 1- (2.5-dihydroxy phenyl) -3-pyridine-2il-propenone, which was obtained from the synthesis of pyridine-2carabaldehyde and 2.5 dihydroxyacetophenone ${ }^{3}$. The mobile phases used were chloroform, $n$ hexane: ethanol (10:1), and n-hexane: 
ethanol (1:2), and the stationary phase used was Silica GF254. The comparison solutions used in this study were 2.5 dihydroxyacetophenone and pyridine2-carbaldehyde compounds. Three TLC plates were prepared with each measuring $10 \mathrm{~cm}$ long and $4 \mathrm{~cm}$ wide, and on each TLC plate, the test solution and comparison solution were placed separately using a micropipette. The TLC plates were inserted into the TLC chambers filled with the mobile phase. After the mobile phase rose to the upper edge of TLC plates, the TLC plates were dried to be read under UV light at a wavelength of $254 \mathrm{~nm}$.

\section{Purity Test with Melting Point Test}

Test for purity with a melting point used the Melting point apparatus. This tool is commonly used to measure the value of the melting point or melting point of a compound. This tool was easy to use. The first thing to do was determining the compound's melting point to be tested; compound 1-(2.5-dihydroxy phenyl)-(3-pyridine-2-yl)-propenone has a melting point of $190.1^{\circ} \mathrm{C}$. The $1-$ (2.5-dihydroxiphenyl) - (3-pyridine-2-il) -propenone compound was crushed using a mortar and a stamper until the test sample became smooth, and the 3$\mathrm{mm}$ test sample was inserted into the capillary tube used in measuring the melting point test. Furthermore, the Melting point apparatus was set at ${ }_{180.1}^{\circ} \mathrm{C} ;$ thus, when the temperature reached $180.1^{\circ} \mathrm{C}$, the capillary tube that had been filled with the test sample was inserted into the hole to identify at what temperature the 1-(2.5- dihydroxiphenyl)-(3-pyridine-2-il)-

propenone compound would melt.

\section{Antimicrobial Activity Test Method with Well Diffusion Method}

\section{Tool Sterilization}

Tool sterilization was necessary to ensure there was no contamination during the test process. The tools were first wrapped in aluminum foil and then sterilized in an autoclave at $121^{\circ} \mathrm{C}$ for 15 minutes. Ose and tweezers were burned with bunsen before being used.

\section{The Making of growth media}

The media used in this study was Nutrient Agar (NA), which was put into 10 Petri dishes, totaling $15 \mathrm{ml}$. The method used was by weighing 4.2 grams of NA, then dissolving the NA with $150 \mathrm{ml}$ of distilled water. Once it was mixed, it was heated until it dissolved completely. After that, the media was sterilized using autoclave at $121^{\circ} \mathrm{C}$ for 15 minutes, and the media was poured into 10 sterilized Petri dishes.

\section{Inoculum Preparation}

The bacteria used in the study were Escherichia coli ATCC 25922 and Enterococcus faecalis ATCC 29212.

a. Rejuvenation of tested bacteria The bacteria were rejuvenated on Nutrient Agar (NA) media. The test microbes were inoculated for one ose into NA and incubated at $37^{\circ} \mathrm{C}$ for 24 hours. The rejuvenation of bacteria was carried out sterilely in Laminar Air Flow (LAF). 
b. The Making of bacterial suspensions

The rejuvenated bacteria were taken for one ose, suspended into $15 \mathrm{ml}$ of sterile $0.9 \% \mathrm{NaCl}$ solution, and then homogenized.

\section{The Making of test solution for}

\section{Escherichia coli ATCC 25922 bacteria}

The preparation of the test solution was carried out by making several variations in volume levels, by weighing $25 \mathrm{mg}$ of 1-(2.5-dihydroxy phenyl)-(3-pyridine-2yl)-propenone compound and adding $10 \mathrm{~mL}$ of DMSO $100 \%$. It was later vortexed until it became homogeneous. It was divided into 3 parts: $A(100 \mu \mathrm{l}), \mathrm{B}(200 \mu \mathrm{l})$, and C (300 $\mu \mathrm{l})$. Each part received DMSO 100\% up to $1000 \mu \mathrm{l}(1 \mathrm{ml})$, and it was re-vortexed until it became homogeneous.

5. The Making of test solution for Enterococcus faecalis ATCC 29212 bacteria

The test solution was made into three levels: $5 \%, 2.5 \%$, and $1.25 \%$. Firstly, the base solution was prepared by weighing $10 \mathrm{mg}$ of the test compound, dissolved in $10 \mathrm{ml}$ of DMSO $100 \%$, and vortexed until it was homogeneous. A total of $5 \%, 2.5 \%$, and $1.25 \%$ of the base solution were taken, and each solution was later added DMSO 100\% up to $1 \mathrm{ml}$ and was vortexed to make it homogeneous.

6. The Making of positive control solutions
The preparation of positive control solutions used amoxicillin trihydrate antibiotics as much as $1 \mathrm{mg} / \mathbf{1 m l}$. In producing the test solution, $1 \mathrm{mg}$ of amoxicillin was dissolved in $1 \mathrm{ml}$ of sterile aqua dest and vortexed until it became homogeneous.

\section{The Making of negative control solutions}

The preparation of negative control solutions used DMSO 100\%. The negative control solution's volume was $1 \mathrm{ml}$, and $1 \mathrm{ml}$ of DMSO $100 \%$ was taken.

\section{Antibacterial activity determination} by using a well method

The method used to determine the antimicrobial activity of 1-(2.5dihydroxiphenyl)-(3-pyridine-2-il)propenone compound was the well method. What needs to be prepared first was a sterile petri dish containing NA media, the test solution, the positive control solution (the antibiotic), and the negative control solution. The test was carried out after all tools had been sterilized in Laminar Air Flow (LAF). Three Petri dishes containing NA media were evenly rubbed with the bacterial suspension solution using cotton buds (sterilized using autoclaving). The Petri cups containing NA media were perforated; each cup had 5 holes. The holes were aimed for the test solution, positive control solution, and negative control solution. 
Each hole was inserted with a test solution of $20 \mu \mathrm{l}$ using a micropipette. Furthermore, the Petri dishes were put into the incubator for 24 hours at $37^{\circ} \mathrm{C}$. After 24 hours, the inhibition zone diameter was observed and measured by three measurement methods.

\section{RESULTS AND DISCUSSION}

\section{Purity test using thin-layer chromatography \\ TLC test used a stationary phase (silica gel} 60 F254) and a mobile phase, adjusted to research by Wibowo (2013), namely, hexane: ethanol (10: 1); hexane: ethanol (1: 2); chloroform. A $0.50 \mu \mathrm{l}$ of 2.5 dihydroxyacetophenone and pyridine-2carbaldehyde compound were spotted on TLC plates with a size of $3 \times 10 \mathrm{~cm}$. The plate that has been spotted with the sample was developed in a TLC chamber filled with hexane: ethanol (10: 1); hexane: ethanol (1: 2); chloroform. The results of TLC that have been developed in the chamber were then observed under $254^{-}$ nm UV light (figure I)

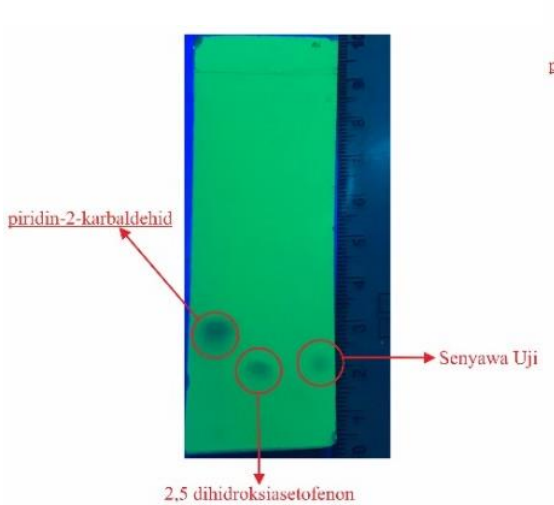

(a)

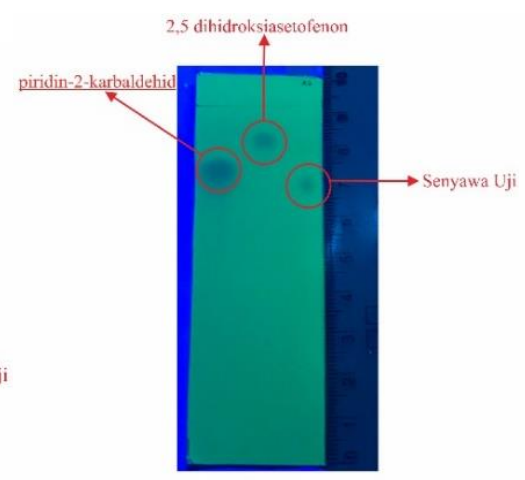

(b)

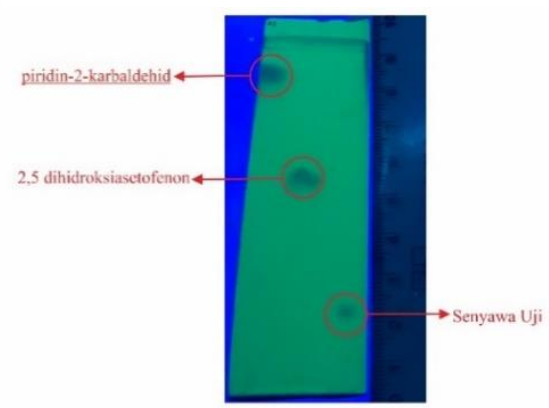

(c)

Figure I. Purity test with TLC. Hexane mobile phase: Ethanol (10: 1) (a); Hexane: Ethanol (1: 2) (b); Chloroform (c).

The purity of the compounds from the analysis using TLC showed that the test compound had a difference in Rf with the material compound, and the test compound spots had only 1 spot. Thus, it can be concluded that the compound was pure by TLC.

\section{Purity test using the melting point}

The results of the melting point test were 190.50C, 190.40C, and 190.50C. These results were similar to the research by Wibowo (2013), which was 190.1. A compound is considered pure if it has a sharp melting point and the melting distance does not exceed $0.5-10 C$.
Therefore, the 1-(2.5-dihydroxiphenyl)-(3pyridine-2-il)-propenone compound used in this study was pure, based on the melting point test.

Table I. Results of the Purity Test of 1-(2.5dihydroxifenyl)-(3-pyridine-2-il)-

\begin{tabular}{cc}
\multicolumn{2}{c}{ propenone by Melting Point Test } \\
\hline Replication & Melting Point $\left({ }^{\circ} \mathrm{C}\right)$ \\
\hline 1 & 190.5 \\
3 & 190.4 \\
& 190.5
\end{tabular}

In addition, the 1-(2.5-dihydroxifenyl)-(3pyridine-2-il)-propenone compound used 
in this study had the same characteristics as those used by Wibowo (2013), for example, in the form of a dark orange solid, sticky, easily soluble in DMSO, insoluble in water and slightly soluble in ethanol.

\section{Antibacterial Activity Test for Escherichia coli ATCC 25922}

The 1-(2.5-dihydroxiphenyl) antibacterial activity test-(3-pyridine-2-il)-propenone compound was carried out by dividing it into 3 volumes: $100 \mu \mathrm{l}, 200 \mu \mathrm{l}$, and $300 \mu \mathrm{l}$. The solvent used to carry out the antibacterial activity test was DMSO
$100 \%$. DMSO $100 \%$ was also used as a negative control, while amoxicillin was used as a positive control. Each volume variant of the 1-(2.5-dihydroxiphenyl)-(3pyridine-2-il)-propenone compound was replicated 3 times. The method was well diffusion, followed by basting the bacteria that have been made into a suspension. Furthermore, holes were made in the media as a place for the test compound, positive control, and negative control. The inhibition zone diameter obtained from the antibacterial activity test can be seen in the following table.

Table II. The result of the antibacterial activity test of the 1-(2.5-dihydroxifenil)-(3-pyridine2-il)-propenone compound against the growth of the Escherichia coli ATCC 25922 bacteria

\begin{tabular}{cccccc}
\hline Volume & \multicolumn{3}{c}{ Replication $(\mathrm{mm})$} & Average $(\mathrm{mm})$ & \pm SD \\
\cline { 2 - 3 } $300 \mu \mathrm{I}$ & $\mathrm{I}$ & $\mathrm{II}$ & $\mathrm{III}$ & & \\
$200 \mu \mathrm{l}$ & 0 & 0 & 0 & 0 & 0 \\
$100 \mu \mathrm{l}$ & 0 & 0 & 0 & 0 & 0 \\
K-(DMSO) & 0 & 0 & 0 & 0 & 0 \\
K+ (Antibiotic) & 12.3 & 12.3 & 10.7 & 11.7 & \pm 0.930
\end{tabular}

*Each replication hole had 3-time measurements.

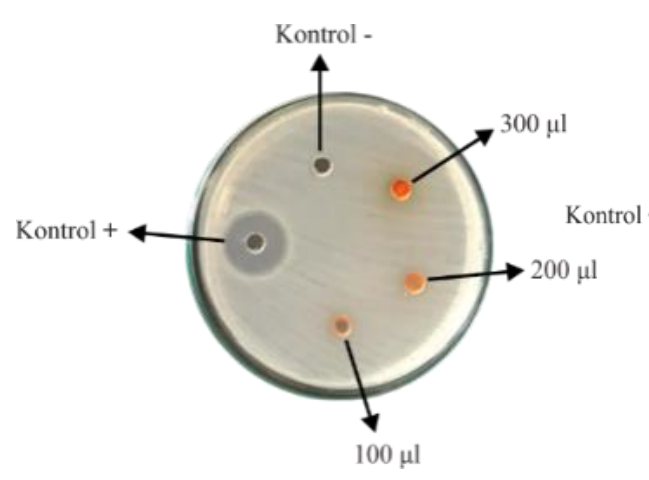

I

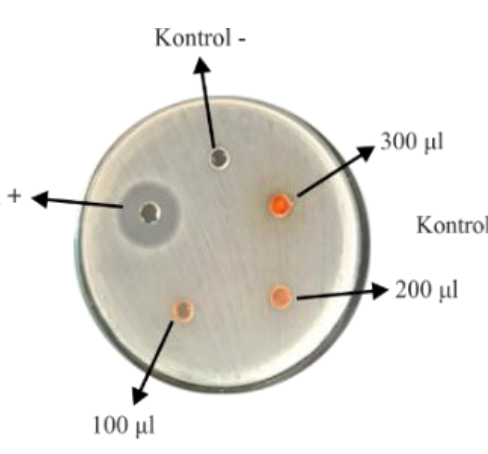

II

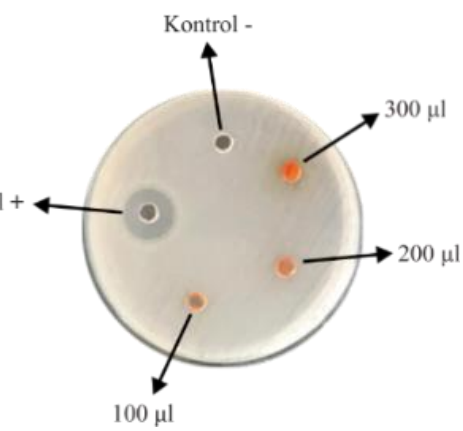

III

Figure II. The test results for the antibacterial activity of 1- (2.5-dihydroxiphenyl) - (3pyridine-2-il) -propenone compound on the growth of Escherichia coli in Experiment I, II, and III. 
Escherichia coli is a gram-negative bacteria, a cumulative anaerobic which can grow in the presence or absence of oxygen. Escherichia coli is also a gramnegative bacterium with multi-layered and complex cell walls, and its outer membrane can work as a variety of compounds, including the antibacterial compound.

Antibacterial Activity Test of Enterococcus faecalis ATCC 29212

Enterococcus faecalis is a gram-positive bacteria belonging to the facultative anaerobic group. Amoxicillin was used as a positive control as it is a broad-spectrum

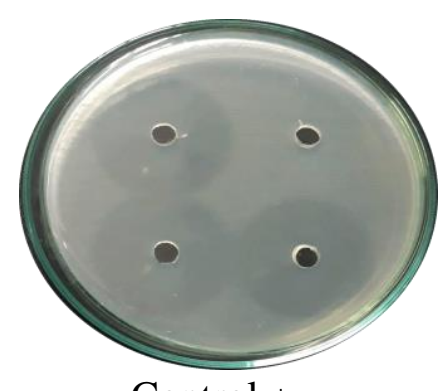

Control +

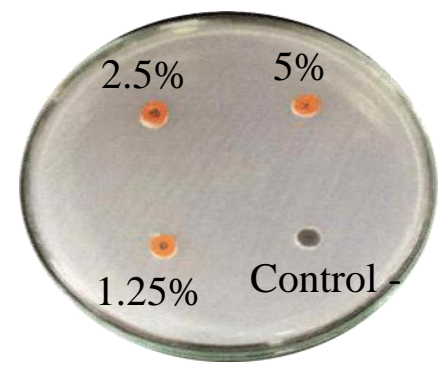

Figure 3. Results of antibacterial activity test of 1-(2.5-dihydroxiphenyl)-3-pyridine-2-ilpropenone

The average inhibition rate of amoxicillin positive control with a concentration of $0.1 \%$ was $26 \mathrm{~mm}$. The criteria for the antibacterial power are as follows: the inhibition zone diameter of $5 \mathrm{~mm}$ or less is categorized as weak, the inhibition zone $5^{-}$ $10 \mathrm{~mm}$ is categorized as moderate, the inhibition zone $10-20 \mathrm{~mm}$ is categorized as

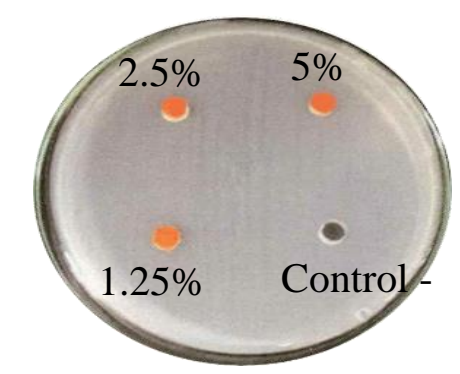

antibiotic that can be used as an antibacterial for gram-negative and grampositive bacteria. Amoxicillin is a semisynthetic penicillin antibiotic that has a $\beta$-lactam ring. The zone of inhibition formed after incubation for 24 hours on media smeared with bacteria was measured using a caliper. The result of the antibacterial activity test can be seen in Figure III. After obtaining the results from the incubation with three repetitions, the inhibition zone was measured, and the results are shown in Table III.

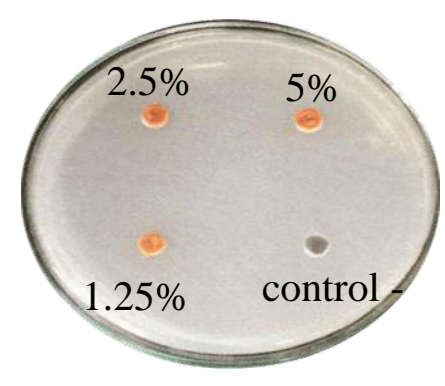

strong, and the inhibition zone of $20 \mathrm{~mm}$ or more is categorized as very strong ${ }^{4}$. Based on the results, amoxicillin antibacterial inhibition against Enterococcus faecalis bacteria was in the category "strong" ( $\geq 20 \mathrm{~mm}$ ). 
Table III. Results of Antibacterial activity test of 1-(2.5-dihydroxiphenyl)-3-pyridine-2-ilpropenone

\begin{tabular}{lccccc}
\hline \multirow{2}{*}{ Concentration } & \multicolumn{2}{c}{ Replication $(\mathrm{mm})$} & & Average & SD \\
\cline { 2 - 4 } & 1 & 2 & 3 & & \\
\hline $5 \%$ & 0 & 0 & 0 & 0 & $\underline{0}$ \\
$2,5 \%$ & 0 & 0 & 0 & 0 & 0 \\
$25 \%$ & 0 & 0 & 0 & 0 & 0 \\
Control - & 0 & 0 & 0 & 0 & 0 \\
Control + & 26 & 26 & 26 & 26 & $\underline{0}$ \\
\hline
\end{tabular}

The inhibition of the 1-(2.5dihydroxyphenyl)-3-pyridine-2-ilpropenone from three concentrations made in three replications was o $\mathrm{mm}$. It indicated none of the three kinds of concentrations of 1-(2.5-dihydroxifenyl)3-pyridine-2-il-propenone $\quad(5 \%, \quad 2.5 \%$, $1.25 \%$ ) caused the effect of inhibiting bacterial growth Enterococcus faecalis. This result was different from the initial hypothesis of this study, where the 1-(2.5dihydroxiphenyl)-3-pyridine-2-ilpropenone compound was considered a chalcone derivative that had the effect of inhibiting the growth of Enterococcus faecalis bacteria.

It was probably due to the functional group in the compound that was unable to inhibit bacterial growth 5 . The lack of sensitivity of chalcone-derived compounds in inhibiting the growth of gram-positive bacteria was due to the absence of specific receptors (protein molecules that receive chemical signals) for the entry of test compounds into bacterial cells ${ }^{6}$. The antibacterial properties of chalcone depend on the group attached to the two aromatic rings, such as the $\mathrm{Cl}, \mathrm{Br}$, and $\mathrm{OH}$ groups? Chalcone is one of the secondary metabolic compounds from the flavonoid group. Flavonoids can inhibit bacterial growth by damaging bacterial cell walls, deactivating enzymes, binding to adhesins, and damaging cell membranes ${ }^{8}$.

\section{CONCLUSION}

The 1-(2.5-dihydroxy phenyl)-(3-pyridine2 -il) -propenone compounds used in the study were proven to be pure. There was one spot on TLC, and the solid was dark orange, sticky, easily dissolved in DMSO, insoluble in water, and slightly soluble in ethanol. Compound 1-(2.5-dihydroxifenil)(3-pyridine-2-il)-propenone, in the antimicrobial test using the well diffusion method, could not inhibit the growth of Escherichia coli and Enterococcus faecalis bacteria.

\section{CONFLICT OF INTEREST}

There are no conflicts of interest in the research.

\section{REFERENCES}

1. Gaikwad, K. V., Gaikwad, S., Jadhav, S. B. (2010). Synthesis of Some Novel Chalcones of Phthalimidoester 
Possessing Good Anti-inflammatory and Antimicrobial Activity. Indian Journal of Chemistry- $B$, 49, pp. 131-136.

2. Diedrich, D. F. (1962). Some New Synthetic Flavonoid Glycosides Related in Structure to Phlorizin. Journal of Medicinal and Pharmaceutical Chemistry, 5, pp. 1054-1062.

3. Wibowo, A. E. (2013). Sintesis dan Uji Aktifitas Antiinflamasi Senyawa 1- (2.5dihidroksifenil)-(3-piridin-2-il)propenon. Tesis. Program Studi Ilmu Farmasi, Fakultas Farmasi, Universitas Gajah Mada.

4. Davis, W. W., \& Stout, T. R. (1971). Disc Plate Method of Microbiological Antibiotic Assay. Applied Microbiology, 22(4), pp. 659-665.

5. Eryanti, Y., Zamri, A., Jasril \& Rahmita. 2010. Sintesis Turunan $2^{\prime}$-hidroksi
Kalkon melalui Kondensasi ClaisenSchmidt dan Uji Aktivitasnya sebagai Antimikroba. Jurnal Natur Indonesia. 12(2), pp. 223-227.

6. Nilawati, A., \& Ansory, H. M. (2017). Aktivitas Antibakteri Pada Senyawa Turunan Kalkon Hasil Sintesis Dari Miristisin Buah Pala. Jurnal Farmasi Indonesia. 14 (2), pp. 154-159.

7. Prasad, Y. R., Kumar, P. R., Deepti, C. A., \& Ramana, M. V. (2006). Synthesis and Antimicrobial Activity of Some Novel Chalcones of 2-Hydroxy-1Acetonapthone and 3-Acetyl Coumarin. Journal of Chemistry, 3(4), pp. 236-241.

8. Cowan, M. M. (1999). Plant Products as Antimicrobial Agents. Clinical Microbiology Reviews, 12(4), pp. 564582. 